\title{
Tumor Necrosis Factor-Alpha Inhibits Expression of Pulmonary Surfactant Protein
}

Jonathan R. Wispé, Jean C. Clark, Barbara B. Warner, Daniel Fajardo, William E. Hull, Ronald B. Holtzman, and Jeffrey A. Whitsett

University of Cincinnati, Department of Pediatrics, Divisions of Pulmonary Biology and Neonatology, Cincinnati, Ohio 45267-0541

\begin{abstract}
Tumor necrosis factor- $\alpha$ (TNF $\alpha)$ decreased the expression of pulmonary surfactant proteins SP-A and SP-B in human pulmonary adenocarcinoma cell lines. The effect of TNF $\alpha$ on SP-A content and mRNA in the pulmonary adenocarcinoma cell line, H441-4, was concentration and time dependent. TNF $\alpha$ decreased the cellular content of SP-A to $<10 \%$ of control $48 \mathrm{~h}$ after addition. TNF $\alpha$ decreased de novo synthesis of SP-A and decreased the accumulation of SP-A in media. SP-A mRNA was decreased within $12 \mathrm{~h}$ of addition of TNF $\alpha$, with nearly complete loss of SP-A mRNA observed after $24 \mathrm{~h}$. Inhibitory effects of TNF $\alpha$ on SP-A mRNA were dose-related with nearly complete inhibition of SP-A mRNA caused by 25 $\mathrm{ng} / \mathrm{ml} \mathrm{TNF} \alpha$. The effects of TNF $\alpha$ on SP-A were distinct from the effects of interferon $\gamma$ which increased SP-A content approximately twofold in $\mathrm{H441-4}$ cells. TNF $\alpha$ also decreased the content of SP-B mRNA. In contrast to the inhibitory effect of TNF $\alpha$ on SP-A and SP-B mRNA, TNF $\alpha$ increased mRNA encoding human manganese superoxide dismutase (Mn-SOD). TNF $\alpha$ did not inhibit growth, alter cell viability or $\beta$-actin mRNA in either cell line.

These in vitro studies demonstrate the marked pretranslational inhibitory effects of the cytokine, TNF $\alpha$, on the expression of pulmonary surfactant proteins, SP-A and SP-B. The results support the concept that macrophage-derived cytokines may control surfactant protein expression. (J. Clin. Invest. 1990. 86:1954-1960.) Key words: adenocarcinoma cell line • control surfactant protein
\end{abstract}

\section{Introduction}

Pulmonary surfactant is a complex mixture of phospholipids and associated proteins that reduces surface tension at the alveolar surface and is essential for normal respiratory function. The surfactant lipids, predominantly dipalmitoyl-phosphatidylcholine, are critical for generation of low surface tension. However, the specific surfactant-associated proteins, SP-A, ${ }^{1}$

This paper was presented in part as an abstract at the meeting of the American Thoracic Society in Boston, MA in May 1990.

Address correspondence to Jonathan R. Wispé, M.D., University of Cincinnati, Dept. of Pediatrics, Divisions of Pulmonary Biology and Neonatology, 231 Bethesda Ave., Cincinnati, OH 45267-0541.

Received for publication 30 January 1990 and in revised form 25 June 1990.

1. Abbreviations used in this paper: ARDS, adult respiratory distress syndrome; Mn-SOD, manganese superoxide dismutase; SP-A, pulmonary surfactant protein-A; SP-B, pulmonary surfactant protein B; SP-C, pulmonary surfactant protein C; TNF $\alpha$, tumor necrosis factor alpha.

J. Clin. Invest.

(C) The American Society for Clinical Investigation, Inc. 0021-9738/90/12/1954/07 \$2.00

Volume 86, December 1990, 1954-1960
SP-B, and SP-C, comprise $<10 \%$ of the total mass of surfactant, but are necessary for surfactant function $(1-3)$ for review. Surfactant protein A, the most abundant surfactant protein, is synthesized and secreted primarily by alveolar type II epithelial cells. SP-A binds and aggregates surfactant phospholipids in the alveolus (4) and confers the unique structural organization of tubular myelin to surfactant lipids in the presence of calcium and surfactant protein B (5). SP-B is a distinct hydrophobic surfactant peptide comprised of 79 amino acid residues and confers surfactantlike activity to phospholipids $(2,3)$ for review. SP-A and SP-B may also play an important role in surfactant metabolism. SP-A inhibits phospholipid secretion and enhances phospholipid reuptake by type II epithelial cells in vitro $(6,7)$. SP-B enhances the uptake of phospholipids by type II cell in vitro (8).

Deficiency or altered function of pulmonary surfactant is associated with several human diseases. Respiratory distress syndrome of the newborn, a leading cause of neonatal morbidity and mortality, is associated with decreased pulmonary surfactant (9). Adult respiratory distress syndrome (ARDS), a common cause of acute respiratory failure in adults, occurs after severe injury, shock, or infection. Whereas the pathogenesis of respiratory failure in patients with ARDS may vary with the heterogeneity of predisposing clinical conditions, abnormalities of surfactant composition and function have been described in $\operatorname{ARDS}(10,11)$.

Tumor necrosis factor is a $17,000-\mathrm{D}$ peptide produced by monocytes and macrophages in response to bacterial lipopolysaccharide, interleukin-2, and various mitogens and was initially described by Carswell et al. as an endotoxin-induced serum factor that caused necrosis of solid tumors (12). Subsequent to that report, diverse biological actions have been ascribed to TNF $\alpha$ (13). TNF $\alpha$ is a potent mediator of immune function and inflammation. The effects of TNF $\alpha$ in vivo include fever, induction of interleukin-1, and activation of polymorphonuclear cells (14). Beutler et al. and others suggested that TNF $\alpha$ may mediate many of the effects of endotoxin (14, 15). Endotoxin increases synthesis and secretion of TNF $\alpha$ by monocytes and macrophages in vitro and in vivo (13). Passive immunization against TNF $\alpha$ reduces the mortality associated with endotoxin challenge in rats (15). Whereas the role of TNF $\alpha$ in the pathogenesis of ARDS has not been conclusively proven, infusion of TNF $\alpha$ causes pulmonary hemorrhage, edema, and inflammation (16). Because of the possible association between TNF $\alpha$ and respiratory failure in adult respiratory distress syndrome, we studied the effects of TNF $\alpha$ on the expression of the surfactant-associated proteins. In the present study, we demonstrate that TNF $\alpha$ is a potent inhibitor of SP-A and SP-B expression.

\section{Methods}

Cell culture. Surfactant protein expression was studied in vitro in human pulmonary adenocarcinoma cell lines, NCI H441-4 and NCI 
H820, which were the kind gifts of A. Gazdar, from the National Cancer Institute, Bethesda, MD. The H441-4 cell line expresses both SP-A and SP-B (17), whereas H820 expresses SP-A, SP-B, and SP-C (18). The H441-4 cells have morphologic features of epithelial cells, containing lipid inclusions and dense cytoplasmic granules, but only rare lamellated intracellular organelles (17). The $\mathrm{H} 820$ cells have morphologic characteristics more closely associated with type II epithelial cells containing lamellar bodies and maintaining a relative cuboidal epithelial morphology in culture (18). For these studies, the H441-4 cells were utilized during passage Nos. 60-75 and were cultured on tissue culture plastic at $37^{\circ} \mathrm{C}$ and $5 \% \mathrm{CO}_{2}$ in RPMI 1640 with $10 \%$ FBS, $100 \mathrm{U} / \mathrm{ml}$ penicillin, $0.25 \mu \mathrm{g} / \mathrm{ml}$ amphotericin, and $100 \mu \mathrm{g} / \mathrm{ml}$ streptomycin (Gibco, Grand Island, NY). Cells were routinely passaged weekly and media changed every $4 \mathrm{~d}$. Cells were grown to $\sim 75 \%$ confluency before exposure to TNF $\alpha$.

H820 cells form nonadherent cultures with epithelial cell characteristics. Experiments were performed on $\mathrm{H} 820$ cells between passages 24 and 50. The $\mathrm{H} 820$ cells were incubated at $37^{\circ} \mathrm{C}$ and $5 \% \mathrm{CO}_{2}$ in RPMI 1640 medium containing $20 \mu \mathrm{g} / \mathrm{ml}$ insulin, $20 \mu \mathrm{g} / \mathrm{ml}$ transferrin, $20 \mathrm{ng} / \mathrm{ml}$ sodium selenite, $50 \mathrm{nM}$ dihydrocortisone, $1 \mathrm{ng} / \mathrm{ml} \mathrm{epi-}$ dermal growth factor, $10 \mu \mathrm{M}$ ethanolamine, $100 \mathrm{pM}$ triiodothyronine, $0.2 \%$ BSA, $0.05 \mathrm{mM}$ sodium pyruvate, $10 \mathrm{mM}$ Hepes (pH 7.2), $2 \mathrm{mM}$ glutamine, $100 \mathrm{U} / \mathrm{ml}$ penicillin, $0.25 \mu \mathrm{g} / \mathrm{ml}$ amphotericin $\mathrm{B}$, and 100 $\mu \mathrm{g} / \mathrm{ml}$ streptomycin (Gibco, Grand Island, NY). Cells were maintained in tissue culture flasks, and the medium was changed approximately every $4 \mathrm{~d}$.

$24 \mathrm{~h}$ before addition of TNF $\alpha$, equal numbers of cells were resuspended in fresh media. H441-4 were counted using a hemocytometer and 100,000 cells seeded into $60-\mathrm{mm}$ tissue culture plates. To normalize $\mathrm{H} 820$ cells, equal amounts of total cellular protein were seeded into 60-mm tissue culture plates. $24 \mathrm{~h}$ after resuspension, TNF $\alpha$ or buffer was added to the cultures. Recombinant human TNF $\alpha$ (Boehringer Mannheim, Inc., Indianapolis, IN) had a specific activity of $2 \times 10^{7}$ $\mathrm{U} / \mathrm{mg}$ and was endotoxin-free as assayed by the manufacturer. Interferon $\gamma$ was purchased from Boehringer Mannheim, Inc. After incubation, medias were recovered and frozen. Cells were harvested by gentle scraping (H441-4) or centrifugation (H820), washed exhaustively in PBS ( $\mathrm{pH} \mathrm{7.4)}$ and frozen at $-80^{\circ} \mathrm{C}$ until analyzed for SP-A content, SP-A mRNA, cellular protein, DNA (19) and dye exclusion (20).

Measurement of $S P$ - $A$. Surfactant protein A was purified from surfactant obtained by lung lavage of a patient with alveolar proteinosis (21). Polyclonal anti-human SP-A antibodies were prepared in goats and New Zealand rabbits by repeated injection of $\sim 1 \mathrm{mg}$ purified SP-A in Freund's complete adjuvant. The antisera was specific for SP-A as demonstrated by immunoblot of surfactant from alveolar lavage and human amniotic fluid. The goat and rabbit antisera were then used as the first and second antibodies in a capture ELISA as previously described (22). Frozen media and cell pellets were thawed immediately before analysis. Frozen $\mathrm{H} 441-4$ cells were sonicated in $500 \mu$ l of phosphate buffer $(150 \mathrm{mM} \mathrm{NaCl}, 50 \mathrm{mM}$ sodium phosphate, pH 7.4 with $0.5 \%$ Nonidet P-40). Each assay plate included a standard curve generated with purified human SP-A (1-100 ng/ml) and four serial dilutions of each cell and media sample. Horseradish peroxidase conjugated antirabbit sera was used for detection, and color developed with 0 -phenylenediamine and $\mathrm{H}_{2} \mathrm{O}_{2}$. Absorbance was determined at $490 \mathrm{~nm}$. Correlation coefficients of the standard curves were 0.95-0.99. Sample dilutions were adjusted to within the linear range of the assay. The SP-A content of the samples was expressed as a percentage of the SP-A content of control samples. Analysis was performed on an Apple IIE computer in line with a Dynatech microtiter plate reader.

$\left[{ }^{35} S\right]$ Methionine labeling. $\mathrm{H} 441-4$ cells were treated with TNF $\alpha$ for $48 \mathrm{~h}$. Thereafter, cells were incubated at $37^{\circ} \mathrm{C}$ for $1 \mathrm{~h}$ in methioninedeficient minimum essential media with $1 \mathrm{mg} /$ liter methionine and 1 $\mathrm{mg} / \mathrm{ml}$ BSA. Newly synthesized SP-A was metabolically labeled by addition of $\left[{ }^{35} \mathrm{~S}\right]$ methionine, $200 \mu \mathrm{Ci} / \mathrm{ml}$ (New England Nuclear, Boston, MA) for $4 \mathrm{~h}$. Media were harvested and frozen at $-80^{\circ} \mathrm{C}$. Cells were harvested, washed extensively, and suspended in $50 \mu \mathrm{l}$ of buffer containing 4\% SDS, $190 \mathrm{mM} \mathrm{NaCl}, 50 \mathrm{mM}$ Tris- $\mathrm{HCl}$ (pH 7.4), 1.5\% Triton X-100, $6 \mathrm{mM}$ EDTA, and $1 \mathrm{mM}$ PMSF. Cells were sonicated and heated for $4 \mathrm{~min}$ at $100^{\circ} \mathrm{C}$. Triplicate aliquots were taken for TCA precipitation to quantitate total $\left[{ }^{35} \mathrm{~S}\right]$ methionine incorporation. Aliquots of cell lysates and media containing $500,000 \mathrm{dpm}$ were immunoprecipitated with rabbit antiserum specific for human SP-A and recombinant protein-G-Sepharose (Sigma Chemical Co., St. Louis, MO). Protein G-bound immunoprecipitates were collected by centrifugation and washed exhaustively. Immunoprecipitated proteins were dissolved in SDS-sample buffer and separated on $12 \%$ polyacylamide slab gels. Proteins were electrophoretically transferred to nitrocellulose, dried, and exposed to Kodak XAR-2 film at $-80^{\circ} \mathrm{C}$ for several days.

Northern blot analysis of SP-A MRNA. Cells were collected, washed once in cold PBS ( $\mathrm{pH} 7.4$ ), and lysed by sonication in $4 \mathrm{M}$ guanidine isothiocyanate (Kodak Laboratory and Specialty Chemicals, Rochester, NY) $0.5 \% N$-lauroyl sarcosine (Sigma Chemical Co., St. Louis, MO), $25 \mathrm{mM}$ sodium citrate, $0.1 \mathrm{M} \beta$-mercaptoethanol, and $0.1 \%$ antifoam A. Total cellular RNA was recovered by centrifugation through 5.7 M cesium chloride. RNA was quantitated by measurement of absorbance at $260 \mathrm{mM}$. Samples containing equal amounts of RNA were fractionated on a $1.2 \%$ agarose, $7 \%$ formaldehyde gel, and transferred to nylon membranes (Nytran; Schleicher \& Schuell, Keene, $\mathrm{NH})$. Membranes were stained with $1 \%$ methylene blue in $0.3 \mathrm{M}$ sodium acetate to assess the integrity of the RNA and to verify the reproducibility of loading. Membranes were baked for $2 \mathrm{~h}$ at $80^{\circ} \mathrm{C}$, prehybridized for $4 \mathrm{~h}$ in $6 \times \mathrm{SSPE}, 10 \times$ Denhardt's, $1 \%$ sodium dodecyl sulfate, and $100 \mu \mathrm{g} / \mathrm{ml}$ denatured salmon sperm DNA at $42^{\circ} \mathrm{C}$. Denhardt's solution contains $0.02 \% \mathrm{BSA}, 0.02 \%$ Ficoll, and $0.02 \%$ polyvinylpyrolidone; SSPE contains $0.1 \mathrm{M} \mathrm{NaCl}, 10 \mathrm{mM} \mathrm{NaPO}_{4}(\mathrm{pH} 7.7)$, and $1 \mathrm{mM}$ EDTA. Hybridization was performed for $18 \mathrm{~h}$ at $42^{\circ} \mathrm{C}$ in $50 \%$ deionized formamide, $6 \times$ SSPE, $5 \times$ Denhardt's, $1 \%$ SDS, 100 $\mu \mathrm{g} / \mathrm{ml}$ denatured salmon sperm DNA and $10 \%$ dextran sulfate. SP-A mRNA was detected by hybridization analysis using a $0.9-\mathrm{kb}$ fragment of the human cDNA labeled by nick translation with $\left[{ }^{32} \mathrm{P}\right] \mathrm{dCTP}(23)$. Mn-SOD mRNA was detected with a $\left[{ }^{32} \mathrm{P}\right] \mathrm{CTP}$-labeled antisense RNA which was transcribed from PGEM 3Z (Promega Biotec, Madison, WI) into which the full-length human Mn-SOD cDNA was subcloned (24). $\beta$-Actin mRNA was determined using a $\left[{ }^{32} \mathrm{P}\right] \mathrm{dCTP}$-labeled $0.4-\mathrm{kb}$ fragment from the $3^{\prime}$ untranslated region of human $\beta$-actin (25). After hybridization, the membranes were washed three times in $6 \times$ SSPE, $1 \%$ SDS at room temperature, and twice in $2 \times$ SSPE, $0.3 \%$ SDS at $42^{\circ} \mathrm{C}$ for $15 \mathrm{~min}$. Membranes were wrapped in plastic wrap and exposed to Kodak X-AR film at $-80^{\circ} \mathrm{C}$. Rehybridization of the membranes with another probe was performed after washing the membrane for $2 \mathrm{~h}$ at $65^{\circ} \mathrm{C}$ in $5 \mathrm{mM}$ Tris-Cl ( $\mathrm{pH} 8$ ), $0.2 \mathrm{mM}$ EDTA, $0.5 \%$ sodium pyrophosphate, and $0.1 \times$ Denhardt's solution. SP-A, Mn-SOD, and $\beta$-actin mRNAs were detected as $2.2-\mathrm{kb}, 1.0-\mathrm{kb}$, and $1.8-\mathrm{kb}$ species, respectively, and quantitated by scanning densitometry of the autoradiograms (Helena Laboratories, Beaumont, TX).

\section{Results}

Cell growth, cell viability, and morphology were not altered by recombinant human TNF $\alpha$ or interferon $\gamma$. After incubation with TNF $\alpha(25$ or $50 \mathrm{ng} / \mathrm{ml})$ for $48 \mathrm{~h}$, there were no detectable changes in light microscopic appearance of $\mathrm{H} 441-4$ or $\mathrm{H} 820$. To assess the effects of TNF $\alpha$ on cell growth, equal numbers of H441-4 cells were treated with TNF $\alpha(25 \mathrm{ng} / \mathrm{ml})$ or buffer for $48 \mathrm{~h}$. Cells were harvested and DNA content measured (19). There was no difference in DNA content between control cells $(183 \pm 23 \mu \mathrm{g} \mathrm{DNA} /$ well, $n=12)$ and TNF $\alpha$-treated cells $(162$ $\mu \mathrm{g} /$ well, $n=12$ ), mean $\pm \mathrm{SD}$. To determine whether TNF $\alpha$ altered membrane permeability and cell viability, TNF $\alpha$ treated and control H441-4 and H820 cells were incubated 


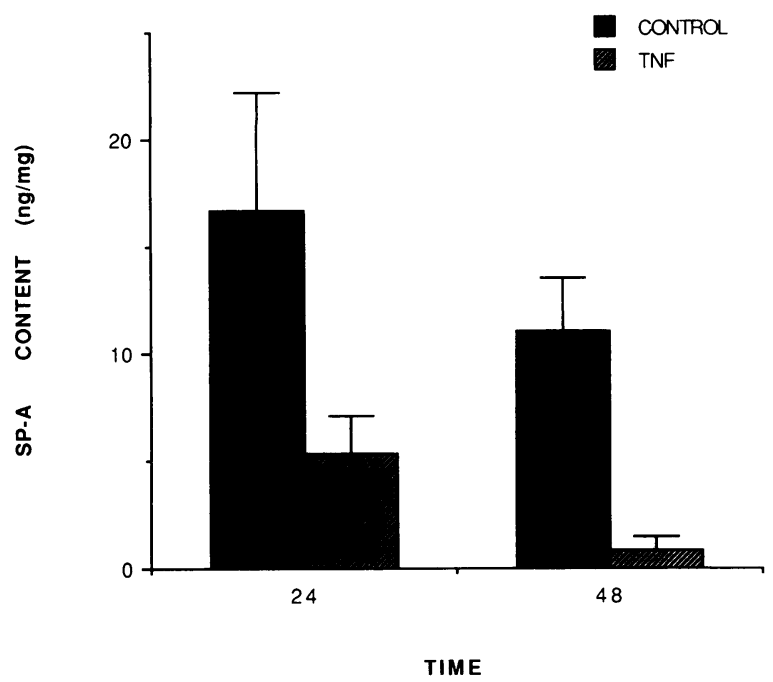

Figure 1. Effect of TNF $\alpha$ on cellular content of SP-A: H441-4 cells were incubated for 24 or $48 \mathrm{~h}$ after addition of TNF $\alpha(25 \mathrm{ng} / \mathrm{ml})$. Cells were washed and sonicated and SP-A measured by ELISA. Data are presented as nanograms SP-A per milligram protein, and represent mean $\pm 1 \mathrm{SD}$ of 12 separate tissue culture plates. SP-A content of TNF $\alpha$-treated cells was significantly less than control at 24 and $48 \mathrm{~h}$, as determined by ANOVA with Newman-Keuls multiple analysis.

with neutral red, a vital dye which is retained only by viable cells (20). Uptake and retention of dye was not altered by TNF $\alpha$.

Effect of TNF $\alpha$ on SP-A content and synthesis. TNF $\alpha$ decreased intracellular and extracellular SP-A content of the H441-4 cells. The amount of SP-A recovered in the media was decreased $48 \mathrm{~h}$ after addition of $25 \mathrm{ng} / \mathrm{ml} \mathrm{TNF} \alpha$, from $891 \pm 302 \mathrm{ng} / \mathrm{ml}($ mean $\pm \mathrm{SD}, n=12)$ in control to $437 \pm 152$ (mean $\pm \mathrm{SD}, n=12$ ) after treatment with TNF $\alpha$. TNF $\alpha$ also decreased content of SP-A within the H441-4 cells (Fig. 1). SP-A content was significantly decreased within $24 \mathrm{~h}$, and was further decreased to $<10 \%$ of control after $48 \mathrm{~h}$. The inhibitory effect of TNF $\alpha$ on intracellular SP-A content was observed whether normalized to total protein or DNA. Treatment of $\mathrm{H} 441-4$ cells with TNF $\alpha$ for $48 \mathrm{~h}$ also decreased the de novo synthesis of SP-A. TNF $\alpha$ decreased $\left[{ }^{35}\right.$ S $]$ methionine incorporation into newly synthesized SP-A both intracellularly and extracellularly in a dose-dependent fashion. De novo synthesis of $\left[{ }^{35}\right.$ S $]$ methionine-labeled SP-A was decreased to $33 \%$ of contents in the intracellular compartment after $48 \mathrm{~h}$ exposure to $50 \mathrm{ng} / \mathrm{ml} \mathrm{TNF} \alpha$, as assessed by scanning densitometry of autoradiograms of radiolabeled SP-A. The effects of TNF $\alpha$ contrasted sharply with those of interferon $\gamma$ which increased SP-A content approximately twofold, from $627 \pm 68$ (mean $\pm \mathrm{SD}, n=6$ ) to $1,029 \pm 66$ (mean $\pm \mathrm{SD}, n=6)$ ng per well after $72 \mathrm{~h}$.

Effect of TNF $\alpha$ on SP-A $m R N A$. Northern blot analysis of total cellular mRNA detected a $2.2 \mathrm{~kb}$ SP-A mRNA, consistent with the previously reported size of SP-A mRNA in human lung tumor cells $(17,18)$. SP-A mRNA decreased in a dose-dependent manner after $48 \mathrm{~h}$ of incubation with TNF $\alpha$ (Fig. $2 a$ ). TNF $\alpha, 1.0 \mathrm{ng} / \mathrm{ml}$, significantly decreased SP-A mRNA (Fig. $2 a$ ). Fig. $2 b$ depicts the densitometric analysis of SP-A mRNA normalized to $\beta$-actin. TNF $\alpha$ neither changed the relative abundance of $\beta$-actin mRNA nor altered the total amount of RNA recovered from the cells. The time course for the loss of SP-A mRNA was assessed after addition of $25 \mathrm{ng} / \mathrm{ml}$ TNF $\alpha$ (Fig. 3). SP-A mRNA was markedly decreased $12 \mathrm{~h}$ after exposure to TNF $\alpha$ and was barely detectable after $24 \mathrm{~h}$. When H441-4 cells were exposed to $25 \mathrm{ng} / \mathrm{ml} \mathrm{TNF} \alpha$ for $24 \mathrm{~h}$, SP-A mRNA content was $21.6 \pm 4 \%$ of control, as assessed by densitometric analysis of Northern blots (Fig. 4). TNF $\alpha$ also decreased SP-A mRNA in a distinct pulmonary adenocarcinoma cell line, NCI-H820. In contrast to the inhibitory effects of TNF $\alpha$ on SP-A mRNA, TNF $\alpha$ consistently increased MnSOD mRNA. The Mn-SOD mRNA was barely detectable in the absence of TNF $\alpha$ and increased markedly after exposure to $\mathrm{TNF} \alpha$ for $48 \mathrm{~h}$ in both $\mathrm{H} 441-4$ (Fig. $5 a$ ) and H820 (Fig. $5 b$ ) cell lines.
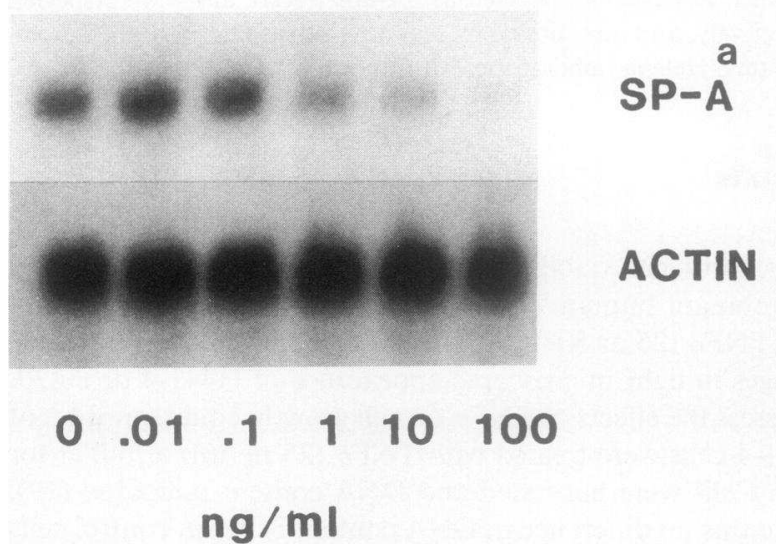

Figure 2. Dose-dependent effect of TNF $\alpha$ on SP-A mRNA: H441-4 cells were incubated $48 \mathrm{~h}$ with increasing concentrations of TNF $\alpha$ (0-100 $\mathrm{ng} / \mathrm{ml})(a)$. RNA was isolated, electrophoresed through a $1.2 \%$ agarose, $7 \%$ formaldehyde gel and transferred to Nytran filters. The filters were hybridized with SP-A [ $\left.{ }^{32} \mathrm{P}\right]$ cDNA, washed clean, and hybridized with $\beta$-actin $\left[{ }^{32} \mathrm{P}\right]$ cDNA. $(b)$ Histogram of the relative abundance of SP-A mRNA normalized to $\beta$-actin as assessed by scanning densitometry. 


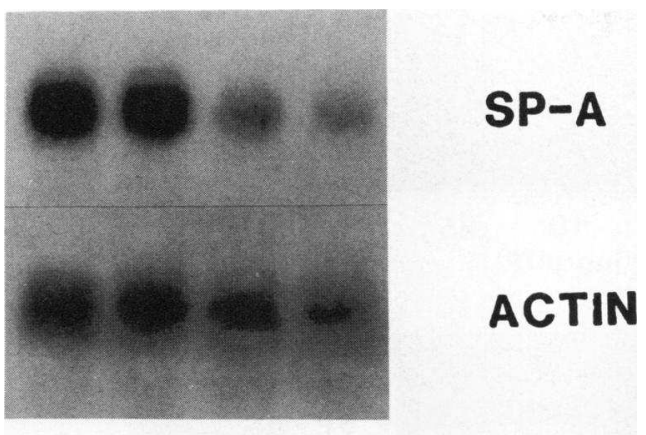

\section{$\begin{array}{llll}0 & 6 & 12 & 24\end{array}$}

\section{Hours}

Figure 3. Time-dependent effect of TNF $\alpha$ on SP-A mRNA: H441-4 cells were harvested at the indicated time points after addition of TNF $\alpha(25 \mathrm{ng} / \mathrm{ml})$. RNA was isolated, electrophoresed through a $1.2 \%$ agarose, $7 \%$ formaldehyde gel, and transferred to Nytran filters. The filters were hybridized with SP-A $\left[{ }^{32} \mathrm{P}\right]$ cDNA, washed clean, and rehybridized with $\beta$-actin $\left[{ }^{32} \mathrm{P}\right]$ cDNA.

Effect of TNF $\alpha$ on SP-B $m R N A$. Northern blot analysis of total cellular mRNA detected a 2.0-kb SP-B mRNA, consistent with the previously reported size of SP-B mRNA in human tumor lines and lung $(17,18)$. The time course for loss of SP-B mRNA was assessed after addition of $25 \mathrm{ng} / \mathrm{ml} \mathrm{TNF} \alpha$ (Fig. 6). SP-B mRNA was decreased within $6 \mathrm{~h}$ and was nearly undetectable $24 \mathrm{~h}$ after exposure to TNF $\alpha$.

\section{Discussion}

Recombinant human TNF $\alpha$ inhibited the expression of surfactant-associated protein $\mathrm{A}$ in human pulmonary adenocarci-
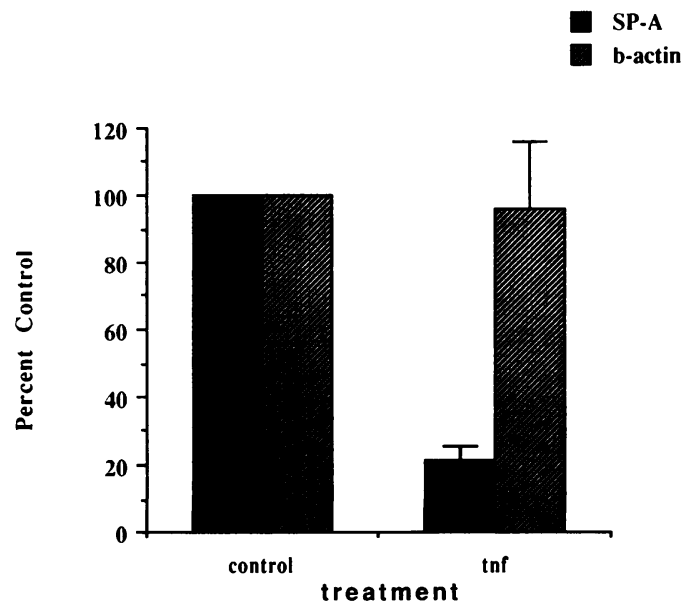

Figure 4. Inhibition of SP-A mRNA by TNF $\alpha$ : H441-4 cells were incubated with TNF $\alpha(25 \mathrm{ng} / \mathrm{ml})$ for $24 \mathrm{~h}$. RNA was isolated and electrophoresed through a $1.2 \%$ agarose, $7 \%$ formaldehyde, and transferred to Nytran. Figure represents the quantitation of scanning densitometry of autoradiograms of RNA from treated and control cells hybridized with the $\left[{ }^{32} \mathrm{P}\right] \mathrm{SP}-\mathrm{A}$ and $\left[{ }^{32} \mathrm{P}\right] \beta$-actin cDNAs. After exposure to TNF $\alpha$ for $24 \mathrm{~h}, \mathrm{SP}-\mathrm{A}$ mRNA was $21.6 \pm 4 \%$ that of control ( $n$ $=12), P<0.05$ by Student's $t$ test. noma cell lines. TNF $\alpha$ decreased SP-A mRNA in association with decreased cellular content of SP-A protein and decreased synthesis and secretion of SP-A. TNF $\alpha$ also decreased the abundance of the mRNA of another surfactant protein, SP-B. The specificity of the inhibitory effects of TNF $\alpha$ on expression of the surfactant proteins was supported by the finding that TNF $\alpha$ increased Mn-SOD expression and did not alter $\beta$-actin mRNA. The inhibitory effects TNF $\alpha$ on SP-A expression were distinct from interferon $\gamma$ which increased SP-A content in the H441 cell line.

The mechanisms involved in decreased SP-A expression after treatment with TNF $\alpha$ appear to be pretranslational. Decreased SP-A mRNA paralleled the decreased synthesis, secretion, and cellular content, suggesting that TNF $\alpha$ affected SP-A through altered gene expression. TNF $\alpha$ is known to alter expression of many proteins, including adipose cell lipogenic enzymes (26) and several muscle-specific genes including alpha cardiac actin and myosin heavy chain (27). Torti et al. showed that the effects of TNF $\alpha$ on adipose cell genes were mediated by changes in gene transcription (26). TNF $\alpha$ increased collagenase production in cultured fibroblasts (28). Brenner and co-workers demonstrated that stimulation of collagenase gene transcription by TNF $\alpha$ was mediated by an element of the gene that is responsive to the transcription factor AP-1. They showed that TNF $\alpha$ produced a prolonged increase in jun gene transcription, and that jun protein interacted with the AP-1 site in the collagenase gene (29).

Most cellular responses to TNF $\alpha$ are initiated by binding to a high-affinity cell surface receptor (30) although not all of the effects of TNF $\alpha$ correlate with the presence of TNF $\alpha$ receptors (31). For some TNF $\alpha$-mediated effects, for example, induction of $\beta_{2}$ interferon, receptor binding appears to lead to activation of protein kinase $C$ (32). Tumor promoting phorbol esters, which directly activate protein kinase $\mathrm{C}$, mimic many of the effects of TNF $\alpha(33,34)$. Recent work from this laboratory demonstrated that the tumor promoting phorbol ester (12-Otetradecanoyl-phorbol-13-acetate [TPA]) decreased SP-A and SP-B expression in the H441-cells (34a). SP-A and SP-B mRNA content decreased more rapidly after TPA than actinomycin $D$, suggesting that transcriptional mechanisms alone do not account for the effects of phorbol esters on SP-A and SP-B expression (34a). The time course for inhibition of SP-A and SP-B mRNA by TNF $\alpha$, is similar to that observed with TPA. However, it remains to be discerned whether the inhibitory effects of TNF $\alpha$ are mediated at the transcriptional or posttranscriptional level, and whether they are mediated by activation of protein kinase $C$.

Human SP-A and SP-B gene expression is regulated by humoral and cellular factors. Surfactant protein synthesis by type II epithelial cells increases during perinatal development and is closely linked to differentiation of distal respiratory epithelial cells (35) for review. In human fetal lung explant cultures, SP-A gene expression is stimulated by cAMP, EGF, $\gamma$ interferon, and glucocorticoids, although both inhibitory and stimulatory effects of glucocorticoids have been observed (17, $35,36)$. SP-A gene expression is inhibited by insulin (37) and TGF- $\beta$ (38). The extent to which transcriptional or posttranscriptional mechanisms control the various hormonal influences on SP-A gene expression remains to be more fully clarified. The finding that TNF $\alpha$ is a potent inhibitor of SP-A gene expression raises the possibility that locally produced monocyte and macrophage derived proteins, may regulate synthesis 


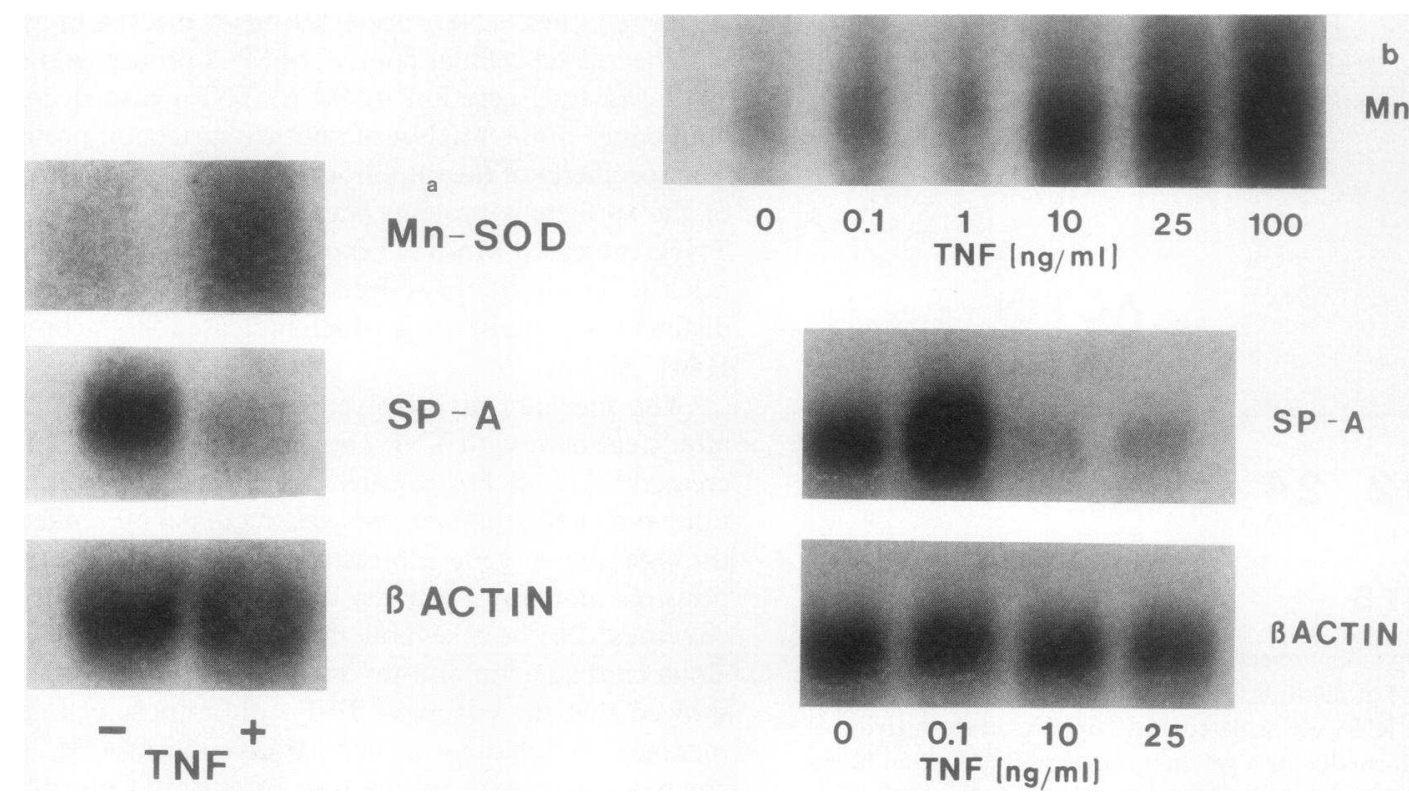

Figure 5. Effects of TNF $\alpha$ on Mn-SOD, SP-A, and $\beta$-actin mRNA: H-441-4 (a) or H-820 $(b)$ cells were harvested $48 \mathrm{~h}$ after the addition of TNF $\alpha(0-100 \mathrm{ng} / \mathrm{ml})$. RNA was isolated, electrophoresed through a $1.2 \%$ agarose, $7 \%$ formaldehyde gel, and transferred to Nytran filters. The filters were hybridized sequentially with ${ }^{32} \mathrm{P}$ labeled Mn-SOD cRNA, SP-A cDNA, and $\beta$-actin cDNA.

of surfactant protein A. In the present study, interferon $\gamma$ stimulated SP-A expression in the $\mathrm{H} 441$ cell line, confirming its stimulatory effects on SP-A synthesis and mRNA previously documented in human fetal lung explant cultures (39). The current results demonstrate that the effects of $\gamma$ interferon are mediated by direct action on the epithelial cells and therefore may be mediated by processes independent of the mesenchyme present in the explant tissues of human fetal lung.

The present studies demonstrate that TNF $\alpha$ also decreases expression of SP-B mRNA in H441 pulmonary adenocarcinoma cells. SP-B is a hydrophobic surfactant protein that increases the rate of absorption of surfactant phospholipids to an air-liquid interface (40) for review. SP-B is expressed by developing epithelial cells of the human fetal lung and its expression is increased by glucocorticoids in the H441-4 and H820 cell lines $(17,18)$, and in human fetal lung explants $(41,42)$. The present findings, that TNF $\alpha$ inhibits both SP-A and SP-B expression are similar to the recently described effects of TPA (34a). In the rat, SP-A and SP-B mRNA increase coordinately during lung development (43); however, SP-A and SP-B mRNA are also subject to distinct regulatory influences (35) for review.

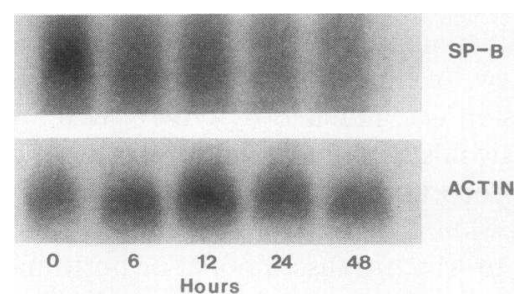

Figure 6. Effect of TNF $\alpha$ on SP-B mRNA: H441-4 cells were incubated with TNF $\alpha(25$ $\mathrm{ng} / \mathrm{ml}$ ) for the indicated times. RNA was isolated, electrophoresed through a $1.2 \%$ agarose, $7 \%$ formaldehyde gel, and transferred to $\mathrm{Ny}$ -

tran filters. The filters were hybridized with SP-B $\left[{ }^{32} \mathrm{P}\right]$ cDNA, washed stringently, and exposed for $3 \mathrm{~d}$.
Administration of TNF $\alpha$ (in vivo) to rodents causes a syndrome similar to septic shock and induces acute lung injury, respiratory insufficiency, and death (44). Histopathologic examination of the lungs from $\mathrm{TNF} \alpha$-treated rodents revealed occlusion of large arteries by neutrophil-rich thrombi, margination of polymorphonuclear leukocytes, interstitial and peribronchiolar pneumonitis, and pleural effusions with alveolar edema (44). Similar histologic alterations are observed in animals treated with endotoxin, and also resemble the pulmonary findings of patients with ARDS. The mechanisms by which infusion of TNF $\alpha$ causes acute lung injury are not completely understood. Activation of complement, induction of a procoagulant endothelial surface, and increased neutrophil production of superoxide anion or secretion of lysomal enzymes have all been observed after TNF $\alpha$ exposure (45). The present work demonstrates a dramatic inhibitory effect of TNF $\alpha$ on surfactant protein expression. However, the current studies utilized pulmonary adenocarcinoma cell lines to study the effects of $\mathrm{TNF} \alpha$ in vitro. Determination of the effects of TNF $\alpha$ on SP-A expression in vivo is complicated by the potential interactions among TNF $\alpha$ and other inflammatory mediators, including interferons, which may have complex and conflicting influences on surfactant protein expression. Whether the deleterious effects of TNF $\alpha$ on lung function in vivo are related to changes in pulmonary surfactant, and specifically to changes in surfactant proteins, remains to be clarified. Nevertheless, our current findings raise the possibility that inflammatory mediators may directly interact with respiratory epithelial cells to alter synthesis of important components of the surfactant system.

\section{Acknowledgments}

The authors acknowledge the technical assistance of Michael S. Burhans. 
Ronald Holtzman was the recipient of a Procter Fellowship Award, Children's Hospital, Cincinnati, OH. This work was supported in part by National Institutes of Health grants HL-28623, HL-39605, Children's Hospital Research Foundation and the American Lung Association.

\section{References} 256.

1. Harwood, J. L. 1987. Lung surfactant. Prog. Lipid Res. 26:211-

2. Weaver, T. E. 1988. Pulmonary surfactant-associated proteins. Gen. Pharmacol. 19:361-368.

3. Hawgood, S. 1989. Pulmonary surfactant apoproteins: a review of protein and genomic structure. Am. J. Physiol. 1:13-22.

4. Hawgood, S., B. J. Benson, and R. L. Hamilton, Jr. 1985. Effects of a surfactant-associated protein and calcium ions on the structure and surface activity of lung surfactant lipids. Biochemistry. 24:184190.

5. Suzuki, Y., Y. Fujita, and K. Kogishi. 1989. Reconstitution of tubular myelin from synthetic lipids and proteins associated with pig pulmonary surfactant. Am. Rev. Respir. Dis. 140:75-81.

6. Rice, W. R., G. F. Ross, F. M. Singleton, S. Dingle, and J. A. Whitsett. 1987. Surfactant-associated protein inhibits phospholipid secretion from type II cells. J. Appl. Physiol. 63:692-698.

7. Dobbs, L. G., J. R. Wright, S. Hawgood, R. Gonzalez, K. Venstrom, and J. Nellenbogen. 1987. Pulmonary surfactant and its components inhibit secretion of phosphatidylcholine from cultured rat alveolar type II cells. Proc. Natl. Acad. Sci. USA. 84:1010-1014.

8. Rice, W. R., V. K. Sarin, J. L. Fox, J. Baatz, S. Wert, and J. A. Whitsett. 1989. Surfactant peptides stimulate uptake of phosphatidylcholine by isolated cells. Biochim. Biophys. Acta. 1006:237-245.

9. Farrell, P. M., and M. A. Avery. 1975. Hyaline membrane disease. Am. Rev. Respir. Dis. 111:657-688.

10. Petty, T. L., G. W. Silvers, G. W. Paul, and R. E. Stanford. 1979. Abnormalities in lung elastic properties and surfactant function in adult respiratory distress syndrome. Chest. 75:571-574.

11. Pison, U., W. Seeger, R. Buchhorn, T. Joka, M. Brand, U. Obertacke, H. Neuhof, and K. P. Schmit-Neubury. 1989. Surfactant abnormalities in patients with respiratory failure after multiple trauma. Am. Rev. Respir. Dis. 140:1033-1039.

12. Carswell, E. A., L. J. Old, R. L. Kassel, S. Green, N. Fiore, and B. Williamson. 1975. An endotoxin-induced serum factor that causes necrosis of tumors. Proc. Natl. Acad. Sci. USA. 72:3666-3670.

13. Kunkle, S. L., D. G. Remick, R. M. Strieter, and J. W. Larrick. 1989. Mechanisms that regulate the production and effects of tumor necrosis factor alpha. Crit. Rev. Immunol. 9:93-117.

14. Beutler, B., I. W. Milsark, and A. C. Cerami. 1985. Passive immunization against cachectin/tumor necrosis factor protects mice from lethal effects of endotoxin. Science (Wash. DC). 229:869-871.

15. Tracey, K. M., T. Fong, D. G. Hess, K. R. Manogue, A. T. Lee, G. C. Kuo, S. F. Lowrey, and A. Cerami. 1987. Anticachectin/TNF monoclonal antibodies prevent septic shock during lethal bacteraemia. Nature (Lond.). 330:662-664.

16. Stephens, K. E., A. Ishizaka, J. W. Larrick, and T. A. Raffin. 1988. Tumor necrosis factor causes increased pulmonary permeability and edema. Am. Rev. Respir. Dis. 137:1364-1370.

17. O'Reilly, M. A., A. F. Gazdar, R. E. Morris, and J. A. Whitsett. 1988. Differential effects of glucocorticoid on expression of surfactant proteins in a human lung adenocarcinoma cell line. Biochim. Biophys. Acta. 970:194-204.

18. O'Reilly, M. A., A. F. Gazdar, J. C. Clark, T. J. Pilot-Matias, S. E. Wert, W. M. Hull, and J. A. Whitsett. 1989. Glucocorticoids regulate surfactant protein synthesis in a pulmonary adenocarcinoma cell line. Am. J. Physiol. 257:L385-L392.

19. Brunk, C. F., K. C. Jones, and T. W. James. 1979. Assay for nanogram quantities of DNA in cellular homogenates. Anal. Biochem. 92:497-500.

20. Finter, N. B. 1969. Dye uptake methods for assessing viral cytopathogenicity and their application to interferon assays. J. Gen. Virol. 5:419-427.

21. Ross, G. F., R. H. Notter, J. Meuth, and J. A. Whitsett. 1986. Phospholipid binding and biophysical activity of pulmonary surfactant-associated protein (SAP)-35 and its non-collagenous $\mathrm{COOH}$-terminal domains. J. Biol. Chem. 261:14283-14291.

22. McMahan, M. J., F. Mimouni, M. Miodovnik, W. M. Hull, and J. A. Whitsett. 1987. Surfactant associated protein (SAP-35) in amniotic fluid from diabetes and non-diabetes pregnancies. Obstet. Gynecol. 70:94-98.

23. Whitsett, J. A., T. Pilot, J. C. Clark, and T. E. Weaver. 1987. Induction of surfactant protein in fetal lung. J. Biol. Chem. 262:52565261 .

24. Wispé, J. R., J. C. Clark, M. S. Burhans, K. E. Kropp, T. R. Korfhagen, and J. A. Whitsett. 1989. Synthesis and processing of the precursor for human mangano-superoxide dismutase. Biochim. Biophys. Acta. 994:30-36.

25. Erba, H. P., P. Gunning, and L. Kedes. 1986. Nucleotide sequence of the human gamma cytoskeletal actin mRNA: anomalous evolution of vertabrate non-muscle actin genes. Nucleic Acid Res. 14:5275-5294.

26. Torti, F. M., B. Dieckmann, B. Beutler, A. Cerami, and G. M. Ringold. 1985. A macrophage factor inhibits adipocyte gene expression: an in vitro model of cachexia. Science (Wash. DC). 229:867-869.

27. Miller, S. C., H. Ito, H. M. Blau, and F. M. Torti. 1988. Tumor necrosis factor inhibits human myogenesis in vitro. Mol. Cell. Biol. 8:2295-2301.

28. Solis-Herruzo, J. A., D. A. Brenner, and M. Chojkier. 1988. Tumor necrosis factor alpha inhibits collagen gene transcription and collagen synthesis in cultured human fibroblasts. J. Biol. Chem. 263:5841-5845.

29. Brenner, D. A., M. O'Hara, P. Angel, M. Chojkier, and M. Karin. 1989. Prolonged activation of jun and collagenase genes by tumor necrosis factor-alpha. Nature (Lond.). 337:661-663.

30. Kull, F. C., S. Jacobs, and P. Cuatrecasas. 1985. Cellular receptor for 125I-labelled tumor necrosis factor: specific binding, affinity labelling, and relationship to sensitivity. Proc. Natl. Acad. Sci. USA. 82:5756-5760.

31. Donato, N. J., G. E. Gallick, P. A. Stock, and M. G. Rosenblum. 1989. Tumor necrosis factor modulates epidermal growth factor receptor phosphorylation and kinase activity in human tumor cells. $J$. Biol. Chem. 264:20474-20481.

32. Sehgal, P. B., Z. Walther, and I. Tamm. 1987. Rapid enhancement of beta2-interferon/B-cell differentiation factor BSF-2 gene expression in human fibroblasts by diacylglycerols and the calcium ionophore A23187. Proc. Natl. Acad. Sci. USA. 84:3663-3667.

33. Zhang, Z., J.-X. Lin, Y. K. Yip, and J. Vilcek. 1988. Enhancement of cAMP levels and of protein kinase activity by tumor necrosis factor and interleukin 1 in human fibroblasts: role in the induction of interleukin 6. Proc. Natl. Acad. Sci. USA. 85:6802-6805.

34. Magnuson, D. K., R. V. Maier, and T. H. Pohlman. 1989. Protein kinase C: a potential pathway of endothelial cell activation by endotoxin, tumor necrosis factor, and interleukin-1. Surgery (St. Louis). 106:216-223.

34a. Pryhuber, G. S., M. A. O'Reilly, J. C. Clark, W. M. Hull, I. Funk, and J. A. Whitsett. 1990. Phorbol ester inhibits surfactant protein SP-A and SP-B expression. J. Biol. Chem. In press.

35. Ballard, P. L. 1989. Hormonal regulation of pulmonary surfactant. Endocr. Rev. 10:165-181.

36. Boggaram, V., M. E. Smith, and C. R. Mendelson. 1989. Regulation of expression of the gene encoding the major surfactant protein $(\mathrm{Sp}-\mathrm{A})$ in human fetal lung in vitro: disparate effects of glucocorticoids on transcription and on messenger RNA stability. J. Biol. Chem. 264:11421-11427. 
37. Snyder, J. M., and C. R. Mendelson. 1987. Insulin inhibits the accumulation of the major lung surfactant apoprotein in human fetal lung explants maintained in vitro. Endocrinology. 120:1250-1257.

38. Whitsett, J. A., T. E. Weaver, M. A. Lieberman, J. C. Clark, and C. Daugherty. 1987. Differential effects of epidermal growth factor and transforming growth factor-B on synthesis of $\mathrm{Mr}=35,000$ surfactantassociated protein in fetal lung. J. Biol. Chem. 262:7908-7913.

39. Ballard, P. L., H. G. Liley, L. W. Gonzales, M. W. Odom, A. J. Ammann, B. Benson, R. T. White, and M. C. Williams. 1990. Interferon-gamma and synthesis of surfactant components by cultured human fetal lung. Am. J. Respir. Cell Mol. Biol. 2:137-143.

40. Possmayer, F. 1988. A proposed nomenclature for pulmonary surfactant-associated proteins. Am. Rev. Respir. Dis. 138:990-998.

41. Whitsett, J. A., T. E. Weaver, J. C. Clark, N. Sawtell, S. W. Glasser, T. R. Korfhagen, and W. M. Hull. 1987. Glucocorticoid enhances surfactant proteolipid Phe and pVal synthesis and RNA in fetal lung. J. Biol. Chem. 262:15618-15623.
42. Liley, H. G., R. T. White, R. G. Warr, B. J. Benson, S. Hawgood, and P. L. Ballard. 1989. Regulation of messenger RNAs for the hydrophobic surfactant proteins in human lung. J. Clin. Invest. 83:1191-1197.

43. Schellhase, D. E., P. A. Emrie, J. H. Fisher, and J. M. Shannon. 1989. Ontogeny of surfactant proteins in the rat. Pediatr. Res. 26:167-174.

44. Tracey, K. J., B. Beutler, S. F. Lowry, J. Merryweather, S. Wolpe, I. W. Milsark, R. J. Hariri, T. J. Fahey, A. Zentella, J. D. Albert, G. T. Shires, and A. Cerami. 1986. Shock and tissue injury induced by recombinant human cachectin. Science (Wash. DC). 234:470-474.

45. Parsons, M. P., G. S. Worthen, E. E. Moore, R. M. Tate, and P. E. Henson. 1989. The association of circulating endotoxin with the development of the adult respiratory distress syndrome. Am. Rev. Respir. Dis. 140:294-301. 